\title{
Technisch werkdocument instellingsrapportages
}

Citation for published version (APA):

Allen, J. P., Ramaekers, G. W. M., \& van der Velden, R. K. W. (2006). Technisch werkdocument instellingsrapportages. Researchcentrum voor Onderwijs en Arbeidsmarkt, Faculteit der Economische Wetenschappen. ROA Working Papers No. 5 https://doi.org/10.26481/umarow.2006005

Document status and date:

Published: 01/01/2006

DOI:

10.26481/umarow.2006005

Document Version:

Publisher's PDF, also known as Version of record

\section{Please check the document version of this publication:}

- A submitted manuscript is the version of the article upon submission and before peer-review. There can be important differences between the submitted version and the official published version of record.

People interested in the research are advised to contact the author for the final version of the publication, or visit the DOI to the publisher's website.

- The final author version and the galley proof are versions of the publication after peer review.

- The final published version features the final layout of the paper including the volume, issue and page numbers.

Link to publication

\footnotetext{
General rights rights.

- You may freely distribute the URL identifying the publication in the public portal. please follow below link for the End User Agreement:

www.umlib.nl/taverne-license

Take down policy

If you believe that this document breaches copyright please contact us at:

repository@maastrichtuniversity.nl

providing details and we will investigate your claim.
}

Copyright and moral rights for the publications made accessible in the public portal are retained by the authors and/or other copyright owners and it is a condition of accessing publications that users recognise and abide by the legal requirements associated with these

- Users may download and print one copy of any publication from the public portal for the purpose of private study or research.

- You may not further distribute the material or use it for any profit-making activity or commercial gain

If the publication is distributed under the terms of Article $25 \mathrm{fa}$ of the Dutch Copyright Act, indicated by the "Taverne" license above, 


\section{Technisch werkdocument instellingsrapportages}

ROA-W-2006/5

Jim Allen, Ger Ramaekers, Rolf van der Velden

Researchcentrum voor Onderwijs en Arbeidsmarkt

Faculteit der Economische Wetenschappen en Bedrijfskunde Universiteit Maastricht

Maastricht, oktober 2006 
ISBN-10: 90-5321-444-5

ISBN-13: 978-90-5321-444-2

sec06.096 


\section{Inhoud}

Pagina

1 Inleiding 1

2 Aspecten die gelden voor alle instellingsrapportages 2

2.1 Conceptueel kader 2

2.2 Vergelijking van instellingscijfers met landelijke cijfers 3

2.3 Overige aspecten 5

3 Aspecten die gelden voor de $\mathrm{HO}$ instellingsrapportages 5

3.1 Rapportcijfers $\quad 5$

$\begin{array}{ll}3.2 \text { Overige aspecten } & 7\end{array}$

4 Monitor-specifieke opmerkingen $\quad 7$

Bijlage $1 \quad$ Kwaliteit van afgestudeerden: een heuristisch kader en indicatoren $\quad 11$

$\begin{array}{lll}\text { Bijlage } 2 & \text { Berekening kwaliteitsindicatoren } \mathrm{HO} & 15\end{array}$

$\begin{array}{lll}\text { Bijlage } 3 & \text { Kwaliteitsindicatoren KUO } & 23\end{array}$

$\begin{array}{lll}\text { Bijlage } 4 & \text { Berekening kwaliteitsindicatoren AVO } & 25\end{array}$

Bijlage $5 \quad$ Berekening kwaliteitsindicatoren BVE 29

$\begin{array}{lll}\text { Bijlage } 6 & \text { Berekening kwaliteitsindicatoren VMBO } & 35\end{array}$ 



\section{Inleiding}

In 2005-2006 is de opzet van de instellingsrapportages voor het hoger onderwijs (HO) in overleg met de HBO-raad, VSNU, hogescholen en universiteiten aangepast om beter aan te sluiten bij het accreditatiekader. Door de nieuwe opzet kunnen hogescholen en universiteiten direct zien welke resultaten voor welk aspect van het accreditatiekader van belang zijn. Om een snel inzicht in de verschillende accreditatieaspecten te vergemakkelijken, zijn deze omgezet in 'rapportcijfers'. Deze laten in een oogopslag zien hoe een opleiding op een bepaald kwaliteitsaspect scoort.

Ook de vorm van de rapportage is vernieuwd. Het doel is om de informatie beter toegankelijk te maken voor de verschillende gebruikers binnen de hogescholen en universiteiten. De rapportage aan de hogescholen en universiteiten vindt op twee manieren plaats. In de eerste plaats in de vorm van een Management Summary. Deze bestaat voor het HO uit de volgende onderdelen:

- Een overzicht van totaalscores van de instelling, en van laag en hoog scorende opleidingen;

- De belangrijkste resultaten van de instelling, geordend naar de verschillende accreditatie aspecten (idem per opleiding);

- Trendcijfers, eveneens geordend naar de verschillende accreditatie aspecten (idem per opleiding);

- Per opleiding kerngegevens over vervolgopleiding, functie en competenties.

Daarnaast wordt de Management Summary digitaal aangeboden. In dit digitale rapport kan verder worden ingezoomd op de indicatoren die ten grondslag liggen aan de scores van de instelling op de accreditatieaspecten. Hierin is tevens alle overige informatie uit de HBO- of WO-Monitor opgenomen, evenals de informatie over de individuele alumni.

De vernieuwing van de instellingsrapportage voor het $\mathrm{HO}$ heeft ook model gestaan voor de vernieuwing van de instellingsrapportages in het kader van de VO-Monitor (AVO instellingsrapportages en VMBO instellingsrapportages) en de BVE-Monitor (BVE instellingsrapportages). In de instellingsrapportages voor AVO, VMBO en BVE staat niet het accreditatiekader als ordeningsprincipe centraal, maar de kwaliteit van de voorbereiding op de arbeidsmarkt of vervolgonderwijs. Ook worden in deze instellingsrapportages vooralsnog geen 'rapportcijfers' gepresenteerd. 


\section{$2 \quad$ Aspecten die gelden voor alle instellingsrapportages}

\subsection{Conceptueel kader}

Bij het beoordelen van de kwaliteit van de resultaten van het onderwijs wordt een drietal functies onderscheiden: de kwalificatiefunctie, de selectiefunctie en de allocatiefunctie. ${ }^{1}$ Bij de kwalificatiefunctie van het onderwijs gaat het om de vraag of het onderwijs de studenten heeft uitgerust met die competenties die relevant zijn voor de doorstroming naar de arbeidsmarkt. De selectiefunctie betreft het beoordelen van studenten op de aanwezige competenties en het op grond hiervan certificeren naar eindniveau. Bij de allocatiefunctie gaat het om de ondersteuning bij de transitie van opleiding naar werk en de aansluiting van de opleiding op het gevonden werk. Voor alle drie functies wordt naar de doeltreffendheid gekeken. Alleen voor de allocatiefunctie wordt ook naar de doelmatigheid gekeken: het externe rendement. Voor een uitgebreide beschrijving van het conceptuele kader wordt verwezen naar Bijlage 1.

Voor elk van de onderscheiden kwaliteitsaspecten (kwalificatie, selectie, allocatie en extern rendement) zijn meerdere indicatoren ontwikkeld. Om een snel inzicht in de verschillende kwaliteitsaspecten te vergemakkelijken, zijn voor het $\mathrm{HO}$ de verschillende indicatoren per kwaliteitsaspect tevens omgezet in een 'rapportcijfer'. Deze rapportcijfers laten in een oogopslag zien hoe een opleiding op een bepaald kwaliteitsaspect scoort. Omdat tevens de waarden van de onderliggende indicatoren worden weergegeven, kan een opleiding gemakkelijk nagaan hoe dit 'rapportcijfer' tot stand is gekomen. Voor elk 'rapportcijfer' en de achterliggende indicatoren worden zowel de cijfers van de betreffende opleiding gepresenteerd als ook de vergelijkbare landelijke cijfers. Dit geeft opleidingen een overzichtelijke en genuanceerde mogelijkheid tot benchmarking.

Voorwaarden voor het indicatorenstelsel

- Wetenschappelijkheid: de indicatoren dienen gebaseerd te zijn op relevante wetenschappelijke inzichten.

- Absolute maatstaf: de indicatoren dienen op zichzelf interpretabel te zijn, en niet afhankelijk van de scores van een andere instelling (zoals het geval wanneer alleen een rangordening wordt gepresenteerd).

- Differentiatie: de indicatoren moeten recht doen aan de verscheidenheid van kwaliteitsdimensies, met aparte indicatoren voor elke dimensie. Juist vanwege deze differentiatie zien we ervan af om tot één oordeel te komen over 'totale kwaliteit'.

- Vergelijkbaarheid: de indicatoren moeten een vergelijking mogelijk maken van verschillende opleidingen binnen instellingen, en van instellingen onderling.

- Inzichtelijkheid: door in te zoomen van algemeen naar specifiek, moet het indicatorenstelsel direct toegankelijk zijn, ook voor niet-ingewijde gebruikers.

1. Peschar, J. \& A. Wesselingh (2001), Onderwijssociologie, Groningen: Wolters-Noordhoff. 
- Efficiëntie: het indicatorenstelsel dient eenvoudig en goedkoop te implementeren zijn, voor zover mogelijk binnen bestaande infrastructuren.

- Robuustheid: voor elk aspect dienen bij voorkeur meerdere indicatoren beschikbaar te zijn om de robuustheid te bevorderen.

- Validiteit en betrouwbaarheid: De indicatoren dienen valide en betrouwbaar te kunnen worden vastgesteld.

\subsection{Vergelijking van instellingscijfers met landelijke cijfers}

Vereist aantal waarnemingen

Voor de instellingen worden altijd cijfers gepresenteerd, ook als deze op minder dan 20 waarnemingen betrekking hebben. De reden hiervoor is dat instellingen altijd interesse hebben in de eigen cijfers, ook als een opleiding weinig afgestudeerden heeft. We drukken in een dergelijk geval de cijfers lichtgrijs af om te benadrukken dat het betreffende cijfer op een gering aantal waarnemingen berust. Voor de landelijke cijfers wordt een ondergrens van 20 waarnemingen ongewogen gehanteerd. ${ }^{2}$ Dit geldt niet alleen voor het landelijk gemiddelde maar ook voor het minimum en maximum. Hierdoor kan het voorkomen dat een instelling met minder dan 20 waarnemingen onder het landelijk minimum of boven het landelijk minimum scoort (deze zijn immers altijd gebaseerd op instellingen met minimaal 20 waarnemingen).

De ondergrens ligt net als vroeger bij $n>=3$, tenzij respondenten hebben aangeven dat hun gegevens herkenbaar aan de instelling mogen worden doorgegeven. In dat geval is $n=1$ of 2 ook toegestaan.

Wanneer een opleiding wel afgestudeerden heeft, maar de respons is nul, dan worden voor die opleiding geen tabellen afgedrukt (géén lege tabellen in de Management Summary).

Instellingscijfers

Naast opleidingscijfers zijn ook instellingscijfers gemaakt om op het niveau van instellingen een snel inzicht te geven hoe de instelling als geheel presteert. Om een zuivere vergelijking met landelijke cijfers te geven, zijn de landelijke cijfers herwogen naar de opleidingssamenstelling van de desbetreffende instelling.

\section{Niveaus voor rapportage}

In de instellingsrapportages worden 3 niveaus onderscheiden: instelling, opleidingscluster (in de meeste gevallen gelijk aan opleiding) en opleiding. In de Management Summary worden instelling en opleidingscluster afgedrukt. In de digitale versie komt bij de variabelencatalogus een knop waarbij de gebruiker kan kiezen voor welk van de 3 niveaus hij de tabel wil.

2. Zie Allen, J. (2006), Tests op betrouwbaarheid en validiteit van kwaliteitsscores voor de resultaten van onderwijs, ROA-W-2006/4 voor een nadere motivering voor deze grens. 
Standaard wordt daar ook het bijbehorend landelijke cijfer bij afgedrukt (voor instelling is dat dus het naar opleidingssamenstelling herwogen landelijke cijfer).

In de digitale versie komt bij de variabelencatalogus tevens een knop waarbij de gebruiker kan kiezen voor welke opleidingsvariant (voltijd/deeltijd/duaal) hij de tabel wil.

Naast deze instellingsrapportage komt in een later stadium een overall rapportage voor het CvB waarin de totale instelling en de faculteiten zijn opgenomen. De opzet hiervan is gelijk aan de huidige papieren versie en zal later worden vastgesteld.

\section{Toetsen van verschillen}

De cijfers van de instelling en de desbetreffende landelijke cijfers zijn niet onafhankelijk van elkaar: in de landelijke cijfers zitten ook de instellingsrespondenten. Om deze reden is besloten om het verschil tussen de eigen instelling en de rest te toetsen. We berekenen een significantie op basis van instelling versus de rest, en presenteren instelling versus het totaal omdat:

* scholen een landelijk gemiddelde willen en geen rest cijfer.

* scholen ook willen weten of ze significant afwijken (en dat moet weer op de rest).

In de instellingsrapportages worden normaal gesproken gewogen landelijke cijfers en ongewogen instellingscijfers gepresenteerd. Mede omdat bij het toetsen de instellingsrespondenten uit de landelijke cijfers worden gehaald, wordt getoetst op ongewogen cijfers. We hanteren de volgende regels:

1. We gebruiken voor het landelijk cijfer altijd het gewogen bestand en voor het instellingscijfers altijd het ongewogen bestand.

2. We toetsen de verschillen tussen de instelling en de 'rest' op basis van het ongewogen bestand.

Het kan dus voorkomen dat het ongewogen instellingscijfer exact gelijk is aan het gewogen landelijk gemiddelde, maar door deze significantieberekening toch significant verschilt van het ongewogen 'rest' cijfer. De kans dat dit voorkomt is echter niet erg groot: het kan alleen voorkomen wanneer de weegfactoren tussen instellingen sterk verschillen. Maar aangezien de hoogte van de weegfactor is begrensd, valt dat waarschijnlijk mee.

Verder is afgesproken om de T-toets zowel voor de percentages als voor de rapportcijfers te gebruiken. Nadere analyse wijst uit dat het voor de berekening van de significatie weinig uitmaakt of de T-toets wordt gebruikt of dat getoetst wordt op het verschil in proporties. Hierbij wordt gekozen voor de T-toets met gelijke varianties. Dat is overigens ook de standaard procedure: verondersteld wordt dat de gemiddelden verschillen, maar dat de varianties gelijk zijn. Bijkomend voordeel is dat het probleem wordt opgelost dat bij veel kleine opleidingen de variantie nul is (omdat iedereen dezelfde score heeft), waardoor elk verschil met het landelijke gemiddelde automatisch significant zou worden. 
Alle significantie toetsen worden uitgevoerd op 10\% niveau 2-zijdig (bij een oneindig aantal df hoort daar een t van 1.645 bij). De scores ${ }^{3}$ van de instelling/opleiding zijn in groen aangegeven indien deze significant (90\% zekerheid) boven de rest liggen, en in rood indien deze significant onder de rest liggen.

Probleem: unieke opleidingen

Door weging gaat het landelijk gemiddelde verschillen van max. en min. Volgend jaar wordt hierover iets opgemerkt in de instellingsrapportages.

\section{$2.3 \quad$ Overige aspecten}

Tabel met trendcijfers

Omdat de laatste 'totaal' kolom het ongewogen gemiddelde over alle gepresenteerde jaren betreft, wordt de kolomtitel "Totaal" veranderd in "Gemiddeld".

Cases met weegfactor $=0$ (non-respondenten) zitten niet in het trendbestand, maar wel in het totaalbestand. Om te voorkomen dat cases met weegfactor $=0$ worden meegenomen in de ongewogen instellingscijfers op basis van het totaalbestand (waardoor trendcijfers kunnen gaan afwijken) moet voor het totaalbestand worden voorgeselecteerd op respons = 1 of respons $=2$ of respons $=10$.

Bij tabellen met trendcijfers (tabel 3.4, 4.4 enz.) kunnen voor selectie en allocatie in sommige jaren geen rapportcijfers worden berekend, omdat meer dan 1 indicator in die jaren niet is gemeten. Om vragen van instellingen te voorkomen, wordt onder aan deze tabellen de volgende toelichting moeten worden opgenomen: "Rapportcijfers zijn niet berekend, wanneer 2 of meer van de onderliggende indicatoren ontbreken".

\section{$3 \quad$ Aspecten die gelden voor de $\mathrm{HO}$ instellingsrapportages}

\subsection{Rapportcijfers}

Uitgangspunt is om de kwaliteitsscores in de vorm van 'rapportcijfers' uit te drukken, omdat rapportcijfers gemakkelijk te interpreteren absolute scores vormen. De algemene werkwijze om te komen tot een rapportcijfer staat beschreven in Bijlage 2 .

3. Voor het HO: rapportcijfers en onderliggende indicatoren. 


\section{Berekeningswijze}

Vanwege zeer zwakke correlaties met de overige indicatoren van de kwalificatiefunctie is het competentieniveau niet in de berekening van het rapportcijfer voor de kwalificatiefunctie opgenomen. $^{4}$

Rapportcijfers worden niet berekend, wanneer 2 of meer van de onderliggende indicatoren vanwege te kleine aantallen ( $<20$ ongewogen) ontbreken.

Gegevens in de Management Summary en rapportcijfers worden uitsluitend berekend voor voltijdse opleidingen.

Alternatieve normen die men kan aanhouden: soepel (grens voor een 6 is $60 \%$ ), matig soepel (grens 70\%), matig streng (= onze norm: 75\%) en streng (grens voor een 6 bij 80\%). Daarnaast kan men per indicator een gewicht bepalen hoeveel het meeweegt in de eindbeoordeling (Bijvoorbeeld 0, 1, 2, 3 of 4).

\section{Vereist aantal waarnemingen}

De rapportcijfers worden uitsluitend berekend wanneer deze betrekking hebben op minimaal 20 waarnemingen ongewogen. Dit geldt zowel voor de landelijke rapportcijfers als de rapportcijfers per instelling. Voor de onderliggende indicatoren geldt dat we voor de instellingen altijd cijfers presenteren, ook als dit op minder dan 20 waarnemingen betrekking heeft. We drukken in een dergelijk geval de cijfers lichtgrijs af om te benadrukken dat het betreffende cijfer op een gering aantal waarnemingen berust. Voor de landelijke cijfers echter handhaven we wel de ondergrens van 20 waarnemingen ongewogen (niet alleen voor het gemiddelde maar ook voor het minimum en maximum).

\section{Toetsen van verschillen van rapportcijfers}

Bij de resultaten voor de totaalscores (kwalfun, selfun, allofun, extfun, profun, persfun, voorfun) geldt dat de standaarddeviatie voor de instellingscijfers altijd 0 is (alle respondenten van de instelling hebben immers dezelfde waarde op deze variabelen). Om dit op te lossen wordt voor elk individu een rapportcijfer per indicator berekend op de volgende wijze, nl: 10 $\left(100-\left(100^{\star} \text { score }\right)\right)^{\star} 4 / 25$ score $=1$ of 0 (in geval van werkloosheid wordt dit: 10 (score)*4/7,5). Vervolgens wordt per aspect per respondent het gemiddelde rapportcijfer berekend en kan de T-toets weer gebruikt worden om het verschil in gemiddelde te toetsen.

4. Zie Allen, J. (2006), Tests op betrouwbaarheid en validiteit van kwaliteitsscores voor de resultaten van onderwijs, ROA-W-2006/4. 


\subsection{Overige aspecten}

Trendcijfers

De variabelen goaarb, goaont, goabre, goadie, ohfnut, ohftevr en ohfcar zijn in 2002 voor het eerst gemeten in een HBO Proeflijst en zijn dus niet voor iedereen van toepassing. Deze HBO Proeflijst betreft slechts een beperkt aantal respondenten en wordt daarom in de trendcijfers niet meegenomen.

\section{Opleidingsclustering}

Voor het KUO worden de opleidingsprofielen gevolgd. Voor het hpo hebben ROA en DESAN samen een voorstel gemaakt. STOAS heeft een voorstel gemaakt voor het hao.

Sterke en zwakke punten van de opleidingen

De instellingsrapportage bevat een overzicht van de aspecten waarop de opleidingen van de desbetreffende instelling bijzonder hoog (rapportcijfer 8 of hoger) of bijzonder laag (rapportcijfer lager dan 6) hebben gescoord. In dit overzicht wordt niet aangegeven of de rapportcijfers significant boven onder de rest van de desbetreffende opleiding liggen. Indien een opleiding niet vermeld wordt, heeft deze op geen enkel aspect bijzonder hoog of bijzonder laag gescoord.

\section{Vermelding respons}

De tabellen en figuren in de Management Summary hebben enkel betrekking op Voltijders. Daarom wortd voor de responsgegevens in paragraaf 3.1 ook enkel de Voltijders genomen. In de digitale versie zijn de tellingen niet uitgesplitst naar $n \_g o v t d t$, dus de aantallen die daar vermeld staan, zijn inclusief deeltijders en dualen.

\section{SPSS-bestand}

De instellingen krijgen een volledig spss-bestand, dus inclusief degenen die niet hebben aangegeven dat hun antwoorden herkenbaar aan de vroegere hogeschool mogen worden doorgegeven. Om deze reden zal het bestand worden geanonimiseerd.

\section{$4 \quad$ Monitor-specifieke opmerkingen}

\section{HAO instellingsrapportage}

In de HBO vragenlijst wordt m.b.t. de competenties gevraagd wat het vereiste en eigen niveau is, en wordt in de clustertabellen (bijv. 4.3) beschreven wat de 3 belangrijkste tekorten en overschotten zijn. 
In de HAO vragenlijst wordt iets anders gemeten: daar wordt gevraagd naar het belang en waar het aspect vooral is geleerd. Hier kunnen dus geen tekorten en overschotten worden berekend. Daarom worden voor het HAO in de clustertabellen (bijv. 4.3) de 3 aspecten weergegeven die te weinig / te veel aan bod zijn gekomen tijdens de opleiding.

De 3 aspecten die te weinig aan bod zijn gekomen, worden bepaald op basis van de variabelen [awba1-awba2-awba3] samen. De 3 aspecten die te veel aan bod zijn gekomen, worden bepaald op basis van de variabelen [atba1-atba2-atba3] samen. Ook hier geldt het criterium 'werkzaam in het kerndomein'.

Tabellenbijlage (rechte tellingen)

In de HAO vragenlijst is een aantal vragen extra gesteld, namelijk:

aansluiting opleiding-vervolgopleiding

-> komt in de tabellenbijlage in het stukje "vervolgopleiding".

mgovb = oordeel voorbereiding op beroepspraktijk

mgopo $=$ oordeel stimulering van de persoonlijke ontwikkeling

mgotot $=$ oordeel opleiding als geheel

wvnto en wvngw variabelen = werkvormen: nadruk tijdens opleiding en nadruk gewenst (11 $\mathrm{x})$

ompgo, ompo, omcgo, omand2 = ervaring met onderwijsmethoden

-> komen in de tabellenbijlage in het stukje "oordeel HBO opleiding".

De 34 HAO werkaspecten waarbij gevraagd is naar het belang en waar het aspect vooral is geleerd?

-> komen in de tabellenbijlage onder het kopje "Belang van werkaspecten, en waar vooral geleerd".

In de HAO vragenlijst is niet gevraagd naar het gemiddeld eindexamencijfer in de hoogst voltooide vooropleiding (excvoh). Voor het kwaliteitsaspect "selectie" in de instellingsrapportage kan de indicator "cijfertoekenning voldoende streng" dus niet worden berekend. Voorgesteld wordt om het rapportcijfer voor "selectie" wel te berekenen, maar dan gebaseerd op drie onderliggende indicatoren. Dit betekent dat de indicator "cijfertoekenning voldoende streng" overal in de HAO instellingsrapportage komt te vervallen (in papieren en elektronische versie; zowel in de tekst als in de figuren en de tabellen).

Verder is in de HAO vragenlijst niet gevraagd naar het oordeel over de huisvesting (mgohv) en het oordeel over de overige materiële voorzieningen (mgomt). Dit betekent dat het kwaliteitsaspect "voorzieningen" overal in de HAO instellingsrapportage komt te vervallen (in papieren en elektronische versie; zowel in de tekst als in de figuren en de tabellen). 


\section{KUO instellingsrapportage}

Afgezien van de afwijkende variabelen is het belangrijkste verschil met de rest van het HBO dat voor de sector kunst geen rapportcijfers worden berekend.

De cijfers in de Management Summary worden gebaseerd op de vragen werkzaam binnen eigen vakgebied (selectie op de variabele bwvg $=1$ of 3 ).

Bijlage 2 en Bijlage 3 van de algemene Management Summary voor het HO komen te vervallen.

\section{AVO instellingsrapportage}

In de vragenlijst staat bij vraag 11 (meer aandacht voor competenties) expliciet: "Zet het belangrijkste bovenaan". Desalniettemin wordt besloten om van elk item te tellen hoe vaak het genoemd is bij tekort1, tekort2 en tekort3, en vervolgens de drie items te nemen die het vaakst genoemd zijn. Afgesproken is om niet met gewichten te werken.

\section{BVE instellingsrapportage}

De indicator "Richting vervolgopleiding past bij opleidingsrichting" wordt berekend door de variabele n_gokop2 (niveau en sector gevolgde opleiding) en n_vokop2 (niveau en sector vervolgopleiding) te vergelijken, en hierbij niet naar niveau maar alleen naar de sector te kijken.

Zowel in de eerste als in de tweede tabel (per paragraaf) zit het aspect "Oordeel opleiding". Voor de eerste tabel moet $\left(n \_w k z p 2=1\right)$ worden genomen, en voor de tweede tabel (n_vvogev = 1).

De drie meest genoemde competenties hoeven niet te worden getoetst. 



\section{Bijlage 1 Kwaliteit van afgestudeerden: een heuristisch kader en indicatoren}

\section{Inleiding}

Vertrekpunt is dat de kwaliteit van het gerealiseerde niveau van onderwijs op basis van twee invalshoeken beoordeeld kan worden: doeltreffendheid en doelmatigheid (Onderwijsraad, 1999). Doeltreffendheid kan worden gedefinieerd als de mate waarin het onderwijs de functies vervult die haar worden toegeschreven. Doeltreffendheid wordt hier overigens beperkt tot doeltreffendheid met betrekking tot de doorstroming naar de arbeidsmarkt. Het onderwijs kan daarnaast ook andere doelstellingen hebben, waarvan de doeltreffendheid geëvalueerd kan worden, maar die worden hier niet behandeld. Doelmatigheid wordt gedefinieerd als de mate van kostenefficiëntie waarmee het onderwijs de functies vervult die zijn omschreven.

In de literatuur wordt een drietal functies onderscheiden die relevant zijn voor een beoordeling van de doeltreffendheid van het onderwijs: de kwalificatiefunctie, de selectiefunctie en de allocatiefunctie (Peschar \& Wesselingh, 2001). ${ }^{5} \mathrm{Bij}$ de kwalificatiefunctie van het onderwijs gaat het om de vraag of het onderwijs de studenten heeft uitgerust met die competenties die relevant zijn voor de doorstroming naar de arbeidsmarkt. De selectiefunctie betreft het beoordelen van studenten op de aanwezige competenties en het op grond hiervan certificeren naar eindniveau. Bij de allocatiefunctie gaat het om de ondersteuning bij de transitie van opleiding naar werk en de aansluiting van de opleiding op het gevonden werk.

Voor elk van de onderscheiden functies van doeltreffendheid kan naar de doelmatigheid worden gekeken. ${ }^{6}$ In deze rapportage zullen we ons echter beperken ${ }^{7}$ tot de doelmatigheid van de allocatiefunctie: het extern rendement. Extern rendement kan voor individuen gedefinieerd worden als de verhouding tussen de opbrengsten van onderwijs over de levensloop en de directe en indirecte kosten om dat onderwijs te kunnen volgen.

5. Een vierde functie die onderscheiden kan worden betreft de socialisatiefunctie van het onderwijs, dat wil zeggen de voorbereiding van studenten op het latere maatschappelijk functioneren. Deze functie komt in de afgestudeerdenmonitor nader aan bod.

6. Bij de kwalificatiefunctie gaat het om het leerrendement (d.w.z. de verhouding van groei in kennis en de instructiekosten), bij de selectiefunctie om het interne rendement (d.w.z. de verhouding van de slaagkans en de verblijfsduur van gediplomeerden en ongediplomeerden) en bij de allocatiefunctie gaat het om het externe rendement (d.w.z. de verhouding van opbrengsten en kosten van het volgen van een opleiding).

7. Empirische gegevens over het leerrendement van opleidingen ontbreken vrijwel geheel, terwijl gegevens over het interne rendement al systematisch worden verzameld door opleidingen. 


\section{De kwalificatiefunctie}

De kwalificatiefunctie draait om de vraag of het onderwijs de studenten afdoende heeft uitgerust met die competenties welke relevant zijn voor de doorstroming naar de arbeidsmarkt. Opleidingen dienen daarbij niet alleen te worden beoordeeld op de vraag of ze hun afgestudeerden voldoende startbekwaam hebben gemaakt voor de arbeidsmarkt (de korte termijn doelstelling van het onderwijs, ofwel startbekwaamheid), maar ook op de vraag of ze een voldoende basis hebben geboden voor de verdere ontwikkeling van 'novice' tot 'expert' (ontwikkelpotentieel) en voor de algehele 'employability' van de afgestudeerden (de lange termijn doelstelling).

In het onderzoek onder de afgestudeerden besteden we uitgebreid aandacht aan de competenties die vereist zijn in de huidige functie en de mate waarin men zelf aangeeft over die competenties te beschikken. In Bijlage 2 is op basis van een uitgebreidere literatuurverkenning (Allen \& van der Velden, 2005a) een nadere uitwerking gegeven van de competenties waarover hoger opgeleiden moeten beschikken. Bovendien is aangegeven op welke wijze de competenties die in de WO-Monitor zijn opgenomen, kunnen worden geclassificeerd naar de Dublin-descriptoren.

Voor de eindbeoordeling van de kwalificatiefunctie is aan de afgestudeerden gevraagd om een aantal overall oordelen te geven. Zo is gevraagd in hoeverre de opleiding een goede basis biedt om te starten op de arbeidsmarkt respectievelijk om kennis en vaardigheden verder te ontwikkelen. Beide items geven een overall oordeel van de afgestudeerden over de korte en lange termijn doelstellingen van het onderwijs. Daarnaast is gevraagd om de opleiding te beoordelen op breedte en diepgang.

\section{De selectiefunctie}

De maatschappelijke legitimering van de kwalificatiefunctie van het onderwijs is voor een belangrijk deel gelegen in de betrouwbaarheid waarmee het onderwijs op deze competenties selecteert. Glebbeek (1988) spreekt in dit verband van het 'middelmatigheidsrisico', dat wil zeggen het risico dat een afgestudeerde beneden een bepaald niveau functioneert. Omdat de 'ware' competenties van een individuele afgestudeerde voor een werkgever slechts met zeer grote kosten zijn te achterhalen, is een oordeel over dit 'middelmatigheidsrisico' bepalend voor het oordeel over de hele groep afgestudeerden. Een afgestudeerde van een opleiding die te boek staat als relatief licht zal daarom meer moeite hebben om een goede baan te vinden, ook als hij of zij zelf over voldoende capaciteiten beschikt, dan een afgestudeerde van een opleiding die de reputatie heeft pittig te zijn.

Over de betrouwbaarheid van de selectie in het onderwijs zijn maar weinig gegevens beschikbaar. Door visitatiecommissies wordt dit doorgaans gecheckt door beoordelingen te maken van enkele werkstukken en dit te vergelijken met de door docenten gegeven beoordelingen. Idealiter vormt een dergelijk systeem van externe ijking van de selectie de beste garantie voor een betrouwbaar selectieproces. Bij ontbreken van een dergelijke externe ijking kunnen alleen proxies gegeven worden van de betrouwbaarheid van de 
selectie. In het onderzoek onder afgestudeerden hebben we drie vragen opgenomen die een indicatie kunnen geven van het 'middelmatigheidsrisico' van de opleiding.

Op de eerste plaats hebben we afgestudeerden gevraagd om aan te geven wat het gemiddelde eindcijfer was voor de opleiding in het WO. Vergelijking van het gemiddelde eindcijfer tussen opleidingen kan een indicatie verschaffen over de betrouwbaarheid van het selectieproces. Bij opleidingen met relatief hoge eindcijfers kan sprake zijn van onvoldoende selectie, bij opleidingen met relatief lage cijfers is wellicht sprake van te zware selectie. Een probleem hierbij is dat het niveau van de studenteninstroom per opleiding kan verschillen. Zoals bekend is er een neiging om cijfers te normeren op het groepsgemiddelde. Daarom wordt het gemiddelde eindcijfer vergeleken met het gemiddelde eindexamencijfer in het voortgezet onderwijs van de betreffende studenten. Hierdoor kan per opleiding een schatting worden gegeven van de mate waarin men - gecorrigeerd voor het aanvangsniveau - een relatief hoog eindcijfer geeft. Daarnaast is aan de afgestudeerden gevraagd om een oordeel te geven over de moeilijkheidsgraad van de opleiding en over de wijze van toetsen en beoordelen. De drie aspecten samen geven een indicatie van het risico dat een student door de selectie komt die niet over de vereiste vaardigheden beschikt.

Vanuit het perspectief van de student heeft de selectiefunctie ook betrekking op de vraag of de opleiding past bij de capaciteiten en verwachtingen van de student (Borghans, 1993). Hoewel de feitelijke keuze voor een opleiding vaak gebaseerd is op zelfselectie, kan een opleiding dit selectieproces wel optimaliseren door goede voorlichting en begeleiding te geven. In het onderzoek onder afgestudeerden hebben we gevraagd om aan te geven of men achteraf gezien opnieuw dezelfde opleiding zou kiezen. Deze zogenaamde spijtvraag geeft aan in welk mate de verwachtingen waarmee een student aan de opleiding is begonnen ook overeen komen met zijn of haar ervaringen achteraf.

Het selectieproces is optimaal wanneer enerzijds de opleiding studenten trekt die over de juiste capaciteiten en belangstelling beschikken om de opleiding te volgen en anderzijds voldoende geselecteerd wordt op relevante competenties om het 'middelmatigheidsrisico' voor werkgevers te minimaliseren.

\section{De allocatiefunctie}

De allocatiefunctie van het onderwijs betreft de vraag of het onderwijs de afgestudeerden op een adequate wijze toeleidt naar de arbeidsmarkt. Hierbij kunnen twee dimensies onderscheiden worden: ondersteuning bij de transitie van opleiding naar werk, en de mate waarin het gevonden werk past bij de opleiding (aansluiting).

De kwaliteit van de ondersteuning die de opleiding biedt bij de transitie van opleiding naar werk is in het onderzoek onder afgestudeerden geïndiceerd door te vragen naar het oordeel van de afgestudeerden over de voorlichting tijdens de opleiding over de beroepsmogelijkheden. 
De kwaliteit van de aansluiting naar de arbeidsmarkt is geïndiceerd door het percentage werkenden dat een baan heeft die aansluit naar het niveau van de gevolgde opleiding ${ }^{8}$, het oordeel van de afgestudeerde over de aansluiting tussen opleiding en werk, de mate waarin men in het werk de eigen capaciteiten goed kan benutten en de tevredenheid met de huidige functie.

\section{Extern rendement}

Extern rendement kan worden gedefinieerd als de verhouding van kosten en opbrengsten van onderwijs die door individuen en de overheid gerealiseerd worden. Het externe rendement is vooral van belang om de macrodoelmatigheid van een opleiding te kunnen beoordelen. Wij beperken ons hier tot het individueel extern rendement. Om het individueel extern rendement te berekenen, zou men de beschikking moeten hebben over zowel de individuele kosten voor het volgen van de opleiding (inclusief de opportuniteitskosten) als de totale opbrengsten over de levensloop. Echter de individuele kosten per opleiding zijn slechts deels bekend en voorzover ze bekend zijn betreft het vaak de kosten die niet variëren tussen opleidingen (bijv. collegegeld). Data over de opportuniteitskosten per opleiding ontbreken geheel, evenals de totale opbrengsten over de levensloop. In het kader van een beoordeling van de (korte termijn) opbrengsten van de opleiding kunnen we echter ook goed volstaan met de volgende indicatoren: het werkloosheidspercentage $1 \frac{1}{2}$ jaar na het verlaten van de opleiding, het bruto uurloon $1 \frac{1}{2}$ jaar na het verlaten van de opleiding en de carrièremogelijkheden van de functie.

Bijlage 3 geeft een specificatie van de wijze waarop de verschillende aspecten (kwalificatie, selectie, allocatie en extern rendement) zijn geoperationaliseerd en hoe deze zijn getransformeerd naar een rapportcijfer.

\section{Literatuur}

Borghans, L. (1993), Educational Choice and Labour Market Information, thesis, Maastricht, Researchcentrum voor Onderwijs en Arbeidsmarkt.

Glebbeek, A.C. (1988), De arbeidsmarktpositie van opleidingen, Tijdschrift voor Arbeidsvraagstukken, 4, 3, pp. 75-89.

Onderwijsraad (1999), Schoolkwaliteit in beeld, Den Haag, Onderwijsraad.

Peschar, J. \& A. Wesselingh (2001), Onderwijssociologie, Groningen: Wolters-Noordhoff.

8. Het percentage werkenden met een baan die aansluit naar de opleidingsrichting is niet als allocatie-indicator opgenomen, omdat analyses hebben aangetoond dat werken buiten de opleidingsrichting niet zonder meer als negatief hoeft te worden beschouwd. Het kan bijvoorbeeld ook wijzen op een hoge mate van flexibiliteit. 


\section{Bijlage 2 Berekening kwaliteitsindicatoren HO}

Bij de berekening van de 'rapportcijfers' hebben we de volgende uitgangspunten gehanteerd:

1. Voor elk aspect (kwalificatie, selectie, allocatie, extern rendement, programma, personeel en voorzieningen) zijn meerdere indicatoren bepaald die gezamenlijk het begrip zo goed mogelijk afdekken.

2. Per indicator is een minimumwaarde bepaald. Waarden lager dan dit minimum geven aan dat de respondent de opleiding op dit aspect duidelijk als onvoldoende beschouwd. Voor 5-puntschalen geldt dat de neutrale middencategorie 3 als minimum wordt gehanteerd (behoudens bij het oordeel over de breedte van de opleiding). Voor rapportcijfers geldt dat het cijfer 6 als minimum wordt gehanteerd.

3. Vervolgens is per aspect het percentage afgestudeerden berekend dat op of boven het minimum zit.

4. Dit percentage is vervolgens omgezet in een rapportcijfer. Hierbij hebben we als norm gehanteerd dat minimaal $75 \%$ op of boven het minimum moet zitten om een 6 te kunnen krijgen. De formule om het percentage om te zetten in een rapportcijfer is: Rapportcijfer $=10-(100-$ Percentage $) * 4 / 25$.

Een uitzondering vormt de omzetting van het werkloosheidspercentage in een rapportcijfer. Dit is als volgt gebeurt: Rapportcijfer voor werkloosheid $=10-(100-$ Percentage) * 4/7,5. Hierdoor scoort bijvoorbeeld $2 \%$ werkloosheid een 8,$9 ; 5 \%$ werkloosheid een 7,3 en $10 \%$ werkloosheid een 4,7 .

5. Om te voorkomen dat cijfers beneden de 6 zwaarder kunnen meewegen dan cijfers boven de 6, zijn alle rapportcijfers lager dan 2 afgerond op 2,0.

6. Het uiteindelijke rapportcijfer bedraagt het gemiddelde van de onderliggende indicatoren.

7. In de rapportages voor hogescholen over individuele opleidingen worden rapportcijfers alleen berekend wanneer de onderliggende indicatoren op mimimaal 20 waarnemingen betrekking hebben. 


\section{Berekening indicatoren voor kwalificatie}

Indicator

Opleiding voldoende basis om te starten op de arbeidsmarkt

Opleiding voldoende basis om competenties verder te ontwikkelen

Opleiding voldoende breed

Opleiding voldoende diepgang
Berekeningswijze

Procentueel aandeel van de afgestudeerden dat vindt dat de opleiding een voldoende basis vormt om te starten op de arbeidsmarkt (score 3, 4 en 5).

Procentueel aandeel van de afgestudeerden dat vindt dat de opleiding een voldoende basis vormt om kennis en vaardigheden verder te ontwikkelen (score 3, 4 en 5).

Procentueel aandeel van de afgestudeerden dat de opleiding voldoende breed vindt (score 3 en $4){ }^{9}$

Procentueel aandeel van de afgestudeerden dat van oordeel is dat de opleiding voldoende diepgang heeft (score 3, 4 en 5).
Vragenlijst

In welke mate biedt uw HBOopleiding een goede basis om te starten op de arbeidsmarkt?

helemaal niet <-> in sterke mate $\begin{array}{lllll}1 & 2 & 3 & 4 & 5\end{array}$

In welke mate biedt uw HBOopleiding een goede basis voor het verder ontwikkelen van kennis en vaardigheden?

helemaal niet <-> in sterke mate $\begin{array}{lllll}1 & 2 & 3 & 4 & 5\end{array}$

Wat is uw oordeel over de breedte van uw HBO-opleiding?

veel te smal <-> veel te breed

$\begin{array}{lllll}1 & 2 & 3 & 4 & 5\end{array}$

Wat is uw oordeel over de diepgang in uw HBO-opleiding?

$\begin{array}{lllr}\text { te weinig } & & & \begin{array}{r}\text { te veel } \\ \text { diepgang }\end{array} \\ \text { diepgang } & <-> & & 5 \\ 1 & 2 & 3 & 4\end{array}$

Het gemiddelde van de bovengenoemde 4 indicatoren voor de kwalificatie.

kwalificatie

9. Nadere analyse wijst uit dat de scores 3 en 4 samenhangen met een goede beoordeling van andere aspecten van de opleiding. Wanneer de opleiding als veel te breed wordt beschouwd (score 5) hangt dit echter negatief samen met de andere oordelen. Het zelfde geldt als de opleiding als te smal wordt beschouwd (scores 1 en 2). 


\section{Berekening indicatoren voor selectie}

Indicator

Cijfertoekenning voldoende streng

Opleiding voldoende zwaar

Oordeel wijze van toetsen en beoordelen

Opleiding opnieuw kiezen

Eindbeoordeling selectie
Berekeningswijze

Gebaseerd op een vergelijking per afgestudeerde van het gemiddelde examencijfer in het hbo en het gemiddelde eindexamencijfer in het havo. ${ }^{10}$ Berekend is het procentuele aandeel van de afgestudeerden waarbij het examencijfer in het hbo gelijk is aan of lager is dan het eindexamencijfer in het havo.

Procentueel aandeel van de afgestudeerden dat de opleiding voldoend moeilijk vindt (score 3, 4 en 5).

Procentueel aandeel van de afgestudeerden dat een rapportcijfer van 6 of hoger toekent aan de wijze van toetsen en beoordelen.

Procentueel aandeel van de afgestudeerden dat achteraf bezien opnieuw voor dezelfde opleiding aan dezelfde onderwijsinstelling zou kiezen.
Vragenlijst

Gemiddeld eindexamencijfer in het havo

$\begin{array}{lllllllll}6 & 6 \frac{1}{2} 2 & 7 & 71 / 2 & 8 & 81 / 2 & 9 & 91 / 2 & 10\end{array}$

Gemiddeld examencijfer hbo

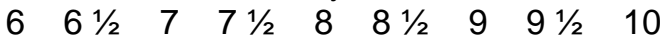

Wat is uw oordeel over de moeilijkheidsgraad van uw HBO-opleiding?

Niet hoog genoeg <-> veel te hoog

$\begin{array}{lllll}1 & 2 & 3 & 4 & 5\end{array}$

Geef een rapportcijfer voor de hieronder genoemde aspecten van de door $u$ gevolgde $\mathrm{HBO}$-opleiding.

"Wijze van toetsen en beoordelen" Geef een afgerond cijfer tussen 1 en 10.

Zou u, achteraf gezien, de door u gevolgde HBO opleiding opnieuw kiezen?

1 ja, dezelfde opleiding aan dezelfde hogeschool

2 ja, dezelfde opleiding maar, aan een andere hogeschool

3 nee, een andere opleiding, namelijk:

4 nee, ik zou niet gaan studeren
Het gemiddelde van de bovengenoemde 4 indicatoren voor selectie.

10. Omdat eindexamencijfers van vwo'ers, havisten en mbo'ers onderling niet vergeleken kunnen worden, is deze berekening uitsluitend uitgevoerd voor hbo'ers met havo als hoogst voltooide vooropleiding. 


\section{Berekening indicatoren voor allocatie}

Indicator

Tevreden over beroepsvoorlichting

Functieniveau past bij opleidingsniveau

Voldoende aansluiting opleiding-werk

Voldoende benutting van capaciteiten

Tevreden met huidige functie

ooordeling allocatie
Procentueel aandeel van de afgestudeerden dat een rapportcijfer van 6 of hoger toekent aan de beroepsvoorlichting.

Procentueel aandeel van de betaald werkende afgestudeerden dat een baan heeft op minstens hbo-niveau (score 1 en 2).

Berekeningswijze

Procentueel aandeel van de betaald werkende afgestudeerden dat een baan heeft die 'voldoende' of 'goed' aansluit bij de opleiding (score 3 en 4). 1 slecht

Procentueel aandeel van de betaald werkende afgestudeerden dat aangeeft dat hun capaciteiten voldoende worden benut (score 3, 4 en 5)

Procentueel aandeel van de betaald werkende afgestudeerden dat tevreden is met de functie (score 3, 4 en 5).

Het gemiddelde van de bovengenoemde 5 indicatoren voor allocatie.
2 matig

3 voldoende

4 goed

Vragenlijst

Geef een rapportcijfer voor de hieronder genoemde aspecten van de door u gevolgde HBO-opleiding.

"Voorlichting over uw beroepsmogelijkheden" Geef een afgerond cijfer tussen 1 en 10.

Welk opleidingsniveau werd door uw werkgever voor deze functie minimaal vereist?

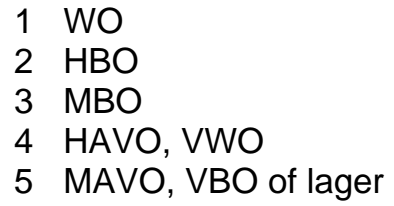

Hoe sluit uw functie aan op uw HBOopleiding?

In welke mate worden uw capaciteiten in uw huidige functie benut? helemaal niet <-> in sterke mate $\begin{array}{lllll}1 & 2 & 3 & 4 & 5\end{array}$ Hoe tevreden bent u met uw huidige functie?

zeer ontevreden <-> zeer tevreden 


\section{Berekening indicatoren voor extern rendement}

Indicator

Werkloosheid

Bruto uurloon

Voldoende carrièremogelijkheden

\section{Eindbeoordeling extern rendement}

Berekeningswijze

Eerst is het werkloosheidspercentage bepaald onder de afgestudeerden. Dit betreft het aantal afgestudeerden dat op zoek is naar betaald werk en minder dan 12 uur per week betaald werkzaam is, gedeeld door het aantal afgestudeerden dat tot de beroepsbevolking behoort (werkenden en werklozen).

Dit percentage is als volgt omgezet in een rapportcijfer: 10(Percentage)*4/7,5.

Hierdoor scoort bijvoorbeeld 2\% werkloosheid een 8,9; 5\% werkloosheid een 7,3 en $10 \%$ werkloosheid een 4,7.

Procentueel aandeel van uurlonen boven drempelinkomen voor hbo'ers. Eerst is een norminkomen voor een gemiddelde hbo'er berekend op basis van het aantal jaren scholing en leeftijd. Het drempelinkomen is het norminkomen verminderd met het inkomen dat hoort bij twee jaren scholing. Het drempelinkomen van hbo'ers bedraagt $€ 9,96$ per uur. In de praktijk betekent dit dat het drempelinkomen dichter bij een mbo- dan bij een hbo-salaris zit.

Procentueel aandeel van de betaald werkende afgestudeerden dat aangeeft dat de functie voldoende carrièremogelijkheden biedt (score 3, 4 en 5).

Het gemiddelde van de bovengenoemde 3 indicatoren voor het externe rendement.
Vragenlijst

Heeft u op dit moment betaald werk?

1 ja

2 nee

Zoekt u op dit moment (ander) betaald werk?

1 ja

2 nee

Gemiddelde arbeidsuren

(leraren: 1 lesuur is 1,5 arbeidsuur)

Reguliere-/contracturen in hoofdfunctie uur per week

Overuren in hoofdfunctie ... uur per week

Uren in andere betaalde baan/banen uur per week

Bruto inkomen volgens contracturen (inclusief toeslagen) in hoofdfunctie

Ongeveer $€$ per maand

Gemiddelde arbeidsuren

(leraren: 1 lesuur is 1,5 arbeidsuur)

Reguliere-/contracturen in hoofdfunctie uur per week

Biedt uw functie goede carrièremogelijkheden?

\begin{tabular}{rrrrr} 
& nauwelijks & $<->$ & & \multicolumn{2}{r}{ heel veel } \\
1 & 2 & 3 & 4 & 5
\end{tabular}




\section{Berekening indicatoren voor oordeel programma}

Indicator

Oordeel opbouw

studie- programma

Berekeningswijze

Procentueel aandeel van de afgestudeerden dat een rapportcijfer van 6 of hoger toekent aan de opbouw van het studieprogramma.

Oordeel keuzemogelijkheden in studie

Procentueel aandeel van de afgestudeerden dat een rapportcijfer van 6 of hoger toekent aan de keuzemogelijkheden in de studie.

Procentueel aandeel van de afgestudeerden dat een rapportcijfer van 6 of hoger toekent aan de samenhang tussen vakken.

hang tussen vakken
Vragenlijst

Geef een rapportcijfer voor de hieronder genoemde aspecten van de door u gevolgde HBO-opleiding. "Opbouw van het studieprogramma" Geef een afgerond cijfer tussen 1 en 10.

Geef een rapportcijfer voor de hieronder genoemde aspecten van de door u gevolgde HBO-opleiding. "Keuzemogelijkheden in studie" Geef een afgerond cijfer tussen 1 en 10.

Geef een rapportcijfer voor de hieronder genoemde aspecten van de door u gevolgde HBO-opleiding. "Samenhang tussen vakken" Geef een afgerond cijfer tussen 1 en 10.

Het gemiddelde van de bovengenoemde 3 indicatoren voor

\author{
programma.
} programma

\section{Berekening indicatoren voor oordeel personeel}

Indicator

Oordeel kwaliteit van docenten

Oordeel studiebegeleiding
Berekeningswijze

Procentueel aandeel van de afgestudeerden dat een rapportcijfer van 6 of hoger toekent aan de kwaliteit van docenten.

Procentueel aandeel van de afgestudeerden dat een rapportcijfer van 6 of hoger toekent aan de studiebegeleiding.

Het gemiddelde van de bovengenoemde 2 indicatoren voor personeel.
Vragenlijst

Geef een rapportcijfer voor de hieronder genoemde aspecten van de door u gevolgde HBO-opleiding. "Kwaliteit van docenten" Geef een afgerond cijfer tussen 1 en 10.

Geef een rapportcijfer voor de hieronder genoemde aspecten van de door u gevolgde HBO-opleiding. "Studiebegeleiding" Geef een afgerond cijfer tussen 1 en 10.
Eindbeoordeling personeel 


\section{Berekening indicatoren voor oordeel voorzieningen}

Indicator

Oordeel

huisvesting

Oordeel overige materiële voorzieningen
Berekeningswijze

Procentueel aandeel van de afgestudeerden dat een rapportcijfer van 6 of hoger toekent aan de kwaliteit van de huisvesting.

Procentueel aandeel van de afgestudeerden dat een rapportcijfer van 6 of hoger toekent aan de overige materiële voorzieningen.

\section{Vragenlijst}

Geef een rapportcijfer voor de hieronder genoemde aspecten van de door u gevolgde $\mathrm{HBO}$-opleiding. "Huisvesting" Geef een afgerond cijfer tussen 1 en 10.

Geef een rapportcijfer voor de hieronder genoemde aspecten van de door u gevolgde HBO-opleiding. "Overige materiële voorzieningen, zoals bibliotheek, mediatheek, werkplaatsen, ict-voorzieningen" Geef een afgerond cijfer tussen 1 en 10.
Eindbeoordeling voorzieningen
Het gemiddelde van de bovengenoemde 2 indicatoren voor voorzieningen. 



\section{Bijlage 3 Kwaliteitsindicatoren KUO}

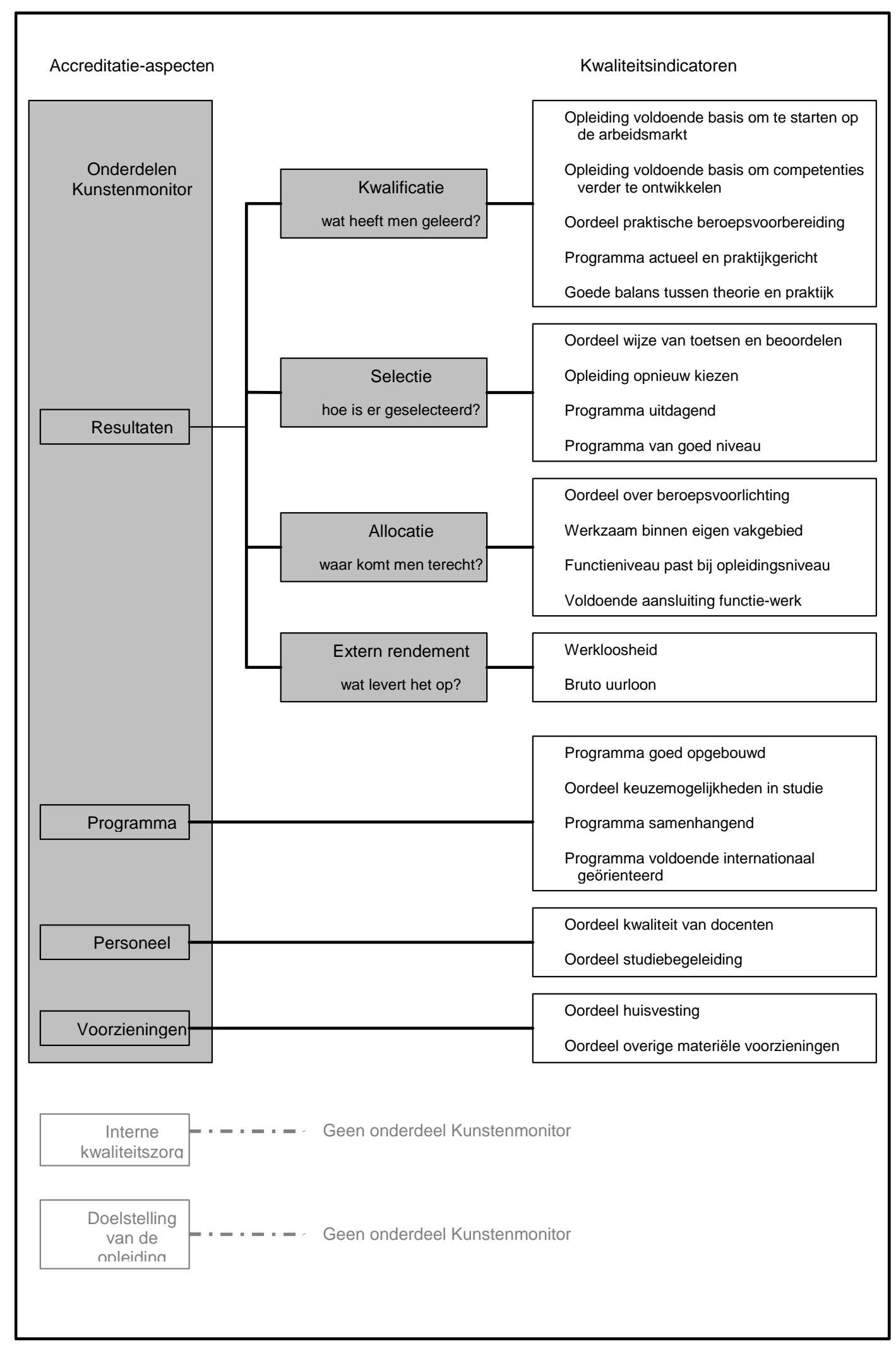





\section{Bijlage 4 Berekening kwaliteitsindicatoren AVO}

\section{Berekening indicatoren voor de kwalificatiefunctie}

Indicator

Voldoende beheersing van het vereiste niveau van competenties

Voldoende voorbereid voor vervolgopleiding

Aan welke competenties moet meer aandacht worden besteed?

\section{Berekeningswijze}

Voor iedere verder lerende

schoolverlater is het percentage van de 12 competenties (zie LINK) berekend, waarbij hij of zij vindt dat het eigen niveau minstens zo hoog is als het niveau dat in de vervolgopleiding is vereist. $^{11}$

Procentueel aandeel van de verder lerende schoolverlaters dat vindt dat de gevolgde HAVO/VWO opleiding hen voldoende of goed (score 3 en 4) heeft voorbereid voor de vervolgopleiding.

Top 3 uit een lijst van 12 competenties (zie LINK)
Vragenlijst

Wat is het vereiste niveau van het genoemde aspect in je vervolgopleiding?

matig $\quad<->\quad$ uitmuntend

Hoe goed beheers je het genoemde aspect?

$$
\begin{array}{llcrr}
\text { matig } & & <-> & \text { uitmuntend } \\
1 & 2 & 3 & 4 & 5
\end{array}
$$

Alle aspecten overziend, hoe goed heeft de gevolgde HAVO/VWO opleiding jou voorbereid voor je vervolgopleiding?

1 slecht

2 matig

3 voldoende

4 goed

Aan welke van de bovengenoemde aspecten had tijdens de gevolgde HAVO/VWO opleiding meer aandacht moeten worden besteed?

11. Schoolverlaters die bij $>4$ competenties een missende waarde hebben zijn bij de berekening niet meegenomen. 


\section{Berekening indicatoren voor de aansluiting naar vervolgonderwijs}

$\begin{array}{ll}\begin{array}{l}\text { Indicator } \\ \text { Niveau } \\ \text { vervolgopleiding }\end{array} & \begin{array}{l}\text { Berekeningswijze } \\ \text { aandeel van de schoolverlaters } \\ \text { dat doorstroomt naar het VWO } \\ \text { of HBO. }\end{array} \\ & \begin{array}{l}\text { Voor vwo'ers, het procentueel } \\ \text { aandeel van de schoolverlaters } \\ \text { dat doorstroomt naar het WO. }\end{array}\end{array}$

Voldoende aansluiting met vervolgonderwijs

Voldoende begeleiding in vervolgonderwijs

Vervolgopleiding achteraf opnieuw kiezen

Procentueel aandeel van de verder lerende schoolverlaters dat de aansluiting tussen de gevolgde HAVO/VWO opleiding en de vervolgopleiding $^{12}$ goed of redelijk vindt (score 1 en 2 ).

Procentueel aandeel van de verder lerende schoolverlaters dat de begeleiding in het eerste jaar van de vervolgopleiding goed of redelijk vindt (score 1 en 2).

Procentueel aandeel van de verder lerende schoolverlaters dat achteraf gezien opnieuw
Vragenlijst

Wat is de naam van deze vervolgopleiding? Vul bij je schooltype je opleidingsrichting in.

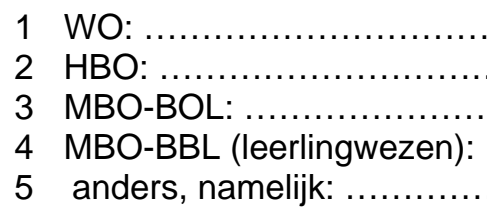

Hoe is de aansluiting tussen de gevolgde HAVO/VWO opleiding en deze vervolgopleiding?
1 goed
2 redelijk
3 matig
4 slecht

Hoe vind je dat je in het eerste jaar van deze vervolgopleiding bent begeleid?
1 goed
2 redelijk
3 matig
4 slecht voor dezelfde vervolgopleiding zou kiezen (score 1 en 2).
Zou je achteraf gezien opnieuw kiezen voor deze vervolgopleiding?

1 ja, ik zou opnieuw kiezen voor deze vervolgopleiding en aan dezelfde school 2 ja, ik zou opnieuw kiezen voor deze vervolgopleiding, maar aan een andere school, namelijk (naam school): 3 nee, ik zou een andere vervolgopleiding kiezen, namelijk: 4 nee, ik zou liever geen vervolgopleiding hebben gevolgd

12. Dit betreft elk type vervolgopleiding. 


\section{Berekening indicatoren voor rendement vervolgonderwijs}

Indicator

$\%$ drop-outs

vervolgonderwijs
Berekeningswijze

Procentueel aandeel van de verder lerende schoolverlaters dat de vervolgopleiding voortijdig heeft verlaten (score 3 ) en op dit moment geen opleiding volgt (score 2).

Procentueel aandeel van de verder lerende schoolverlaters dat de vervolgopleiding voortijdig heeft verlaten (score 3 ) en op dit moment opnieuw een opleiding volgt (score 1).
Vragenlijst

Volg je deze vervolgopleiding nog steeds?

1 ja

2 nee, diploma behaald 3 nee, voortijdig verlaten

Volg je op dit moment een opleiding? (géén cursus)

1 ja, namelijk:

2 nee

Volg je deze vervolgopleiding nog steeds?

1 ja

2 nee, diploma behaald

3 nee, voortijdig verlaten

Volg je op dit moment een opleiding?

1 ja, namelijk:

2 nee 


\section{Berekening indicatoren voor oordeel over begeleiding tijdens HAVO/VWO}

Indicator

Tevreden over hulp bij keuze studieprofiel

Tevreden over gekozen studieprofiel

Tevreden over studie- en beroepskeuzebegeleiding

Voldoende kwaliteit SBKV informatie

\section{Berekeningswijze}

Procentueel aandeel van de schoolverlaters dat tevreden is over de ontvangen hulp bij de keuze van het vakkenpakket/profiel (score 3, 4 en 5).

Procentueel aandeel van de schoolverlaters dat achteraf gezien het gevolgde vakkenpakket/profiel opnieuw zou kiezen (score 1).

Procentueel aandeel van de schoolverlaters dat tevreden is over de ontvangen hulp bij de keuze van een vervolgopleiding of een beroep (score 3, 4 en 5).

Voor iedere schoolverlater is het percentage van de 9 SBKV onderwerpen (zie LINK) berekend, waarvan hij of zij de kwaliteit voldoende vindt (score 1 en 2 ). ${ }^{13}$

\section{Vragenlijst}

Hoe tevreden ben je over de hulp die je hebt gehad bij de keuze van je vakkenpakket/profiel?

zeer ontevreden <-> zeer tevreden

$\begin{array}{lllll}1 & 2 & 3 & 4 & 5\end{array}$

Zou je achteraf gezien het door jou gevolgde vakkenpakket/profiel opnieuw kiezen?

\section{1 ja}

2 nee

Hoe tevreden ben je over de hulp die je hebt gehad bij de keuze van een vervolgopleiding of een beroep?
zeer ontevreden <-> zeer tevreden

$\begin{array}{lllll}1 & 2 & 3 & 4 & 5\end{array}$

Vul voor elk onderwerp in of je de informatie daarover goed, redelijk, matig of slecht vond of dat je over dat onderwerp geen informatie hebt gehad.

Kwaliteit van de informatie

$\begin{array}{ccrrr}\text { goed redelijk matig slecht } & \begin{array}{r}\text { Geen } \\ \text { info } \\ \text { gehad }\end{array} \\ 1 & 2 & 3 & 4 & 5\end{array}$

13. Schoolverlaters die bij $>3$ aspecten een missende waarde hebben zijn bij de berekening niet meegenomen. 


\section{Bijlage 5 Berekening kwaliteitsindicatoren BVE}

\section{Berekening indicatoren voor de kwalificatiefunctie}

Indicator

Voldoende aandacht besteed aan competenties

Voldoende competenties voor uitoefenen functie

Aan welke competenties moet meer aandacht worden besteed?

\section{Berekeningswijze}

Voor iedere betaald werkende schoolverlater is het percentage van de 18 competenties (zie LINK) berekend waarvan hij of zij vindt dat deze voldoende aandacht hebben gekregen (score 1 en 2). ${ }^{14}$

Procentueel aandeel van de betaald werkende oud-cursisten dat vindt dat de kennis en vaardigheden niet tekort schieten voor de huidige functie (score 1 , 2 en 3).

Top 3 (op basis van score 3 ) uit een lijst van 18 competenties (zie LINK).
Vragenlijst

Gewenste aandacht tijdens de opleiding

1 minder aandacht

2 evenveel aandacht

3 meer aandacht

In welke mate schieten je kennis en vaardigheden tekort voor je huidige functie?

$\begin{array}{lrrr}\text { helemaal } & & \\ \text { niet } & & <-> & \text { in sterke mate } \\ 1 & 2 & 3 & 4\end{array}$

Gewenste aandacht tijdens de opleiding

1 minder aandacht

2 evenveel aandacht

3 meer aandacht

14. Oud-cursisten die bij $>5$ competenties een missende waarde hebben, zijn bij de berekening niet meegenomen. 


\section{Berekening indicatoren voor de allocatiefunctie (aansluiting naar arbeidsmarkt)}

Indicator

Functieniveau past bij opleidingsniveau

Voldoende aansluiting opleiding-werk

Voldoende benutting van kennis en vaardigheden

Tevreden met huidige functie

\section{Berekeningswijze}

Procentueel aandeel van de betaald werkende oud-cursisten dat een baan heeft op tenminste het eigen niveau.

Procentueel aandeel van de betaald werkende oud-cursisten dat een baan heeft die 'goed' of 'redelijk' aansluit bij de opleiding (score 1 en 2).

Procentueel aandeel van de betaald werkende oud-cursisten dat aangeeft dat hun kennis en vaardigheden voldoende worden benut (score 3, 4 en 5).

Procentueel aandeel van de betaald werkende oud-cursisten dat tevreden is met de functie (score 3, 4 en 5).
Vragenlijst

Vereist opleidingsniveau door werkgever

1 basisonderwijs

2 VMBO, VBO of MAVO

3 HAVO of VWO

4 MBO-BOL/BBL niveau 1 of 2

$5 \mathrm{MBO}-\mathrm{BOL} / \mathrm{BBL}$ niveau 3 of 4

$6 \mathrm{HBO}$ of WO

Hoe is de aansluiting tussen de gevolgde BOL/BBL opleiding en je huidige functie?
1 goed
2 redelijk
3 matig
4 slecht

In welke mate worden in je huidige functie je kennis en vaardigheden benut?

helemaal niet <-> in sterke mate

$$
\begin{array}{lllll}
1 & 2 & 3 & 4 & 5
\end{array}
$$

Hoe tevreden ben je met je huidige functie?

zeer ontevreden <-> zeer tevreden

$\begin{array}{lllll}1 & 2 & 3 & 4 & 5\end{array}$

\section{Berekening indicatoren voor de allocatiefunctie (aansluiting vervolgonderwijs)}

Indicator

Richting vervolgopleiding past bij opleidingsrichting

Voldoende aansluiting met vervolgonderwijs
Berekeningswijze

Procentueel aandeel van de verder lerende oud-cursisten met een vervolgopleiding die formeel aansluit bij de opleidingsrichting.

Procentueel aandeel van de verder lerende oud-cursisten dat de aansluiting tussen de gevolgde BOL/BBL opleiding en de vervolgopleiding 'goed' of 'redelijk' vindt (score 1 en 2).
Vragenlijst

Wat is de naam van deze vervolgopleiding? Vul bij je schooltype je opleidingsrichting in.
$1 \mathrm{HBO}$
2 MBO-BOL:
3 MBO-BBL(leerlingwezen):
4 anders, namelijk:

Hoe is de aansluiting tussen de gevolgde BOL/BBL opleiding en deze vervolgopleiding?
1 goed
2 redelijk
3 matig
4 slecht 


\section{Berekening indicatoren voor het extern rendement van oud-cursisten die zijn gaan werken}

Indicator

Werkloosheid

Bruto uurloon

Voldoende carrièremogelijkheden

\section{Berekeningswijze}

Binnen de groep oud-cursisten die behoort tot de beroepsbevolking (werkenden + werklozen): het percentage oud-cursisten dat zoekt naar betaald werk en op dit moment minder dan 12 uur per week werkzaam is.

\section{Vragenlijst}

Heb je op dit moment betaald werk of volg je een opleiding in het kader van $\mathrm{BBL}$ of $\mathrm{HBO}$ duaal?

1 ja

2 nee

Zoek je op dit moment (ander) werk?

1 ja

2 nee

Aantal arbeidsuren volgens contract uur per week

Het bruto uurloon is gelijk aan het bruto maandloon gedeeld door het aantal arbeidsuren per week, vermenigvuldigt met de factor 12/52.

Bruto inkomen per maand (exclusief overuren; inclusief toeslagen)

ongeveer. EURO per maand

Aantal arbeidsuren volgens contract (overuren, uren op school (bij BBL, HBO duaal) niet meetellen)

uur per week

Procentueel aandeel van de betaald werkende oud-cursisten dat aangeeft dat de functie voldoende carrièremogelijkheden biedt (score 3 , 4 en 5). 


\section{Berekening indicatoren voor rendement vervolgonderwijs}

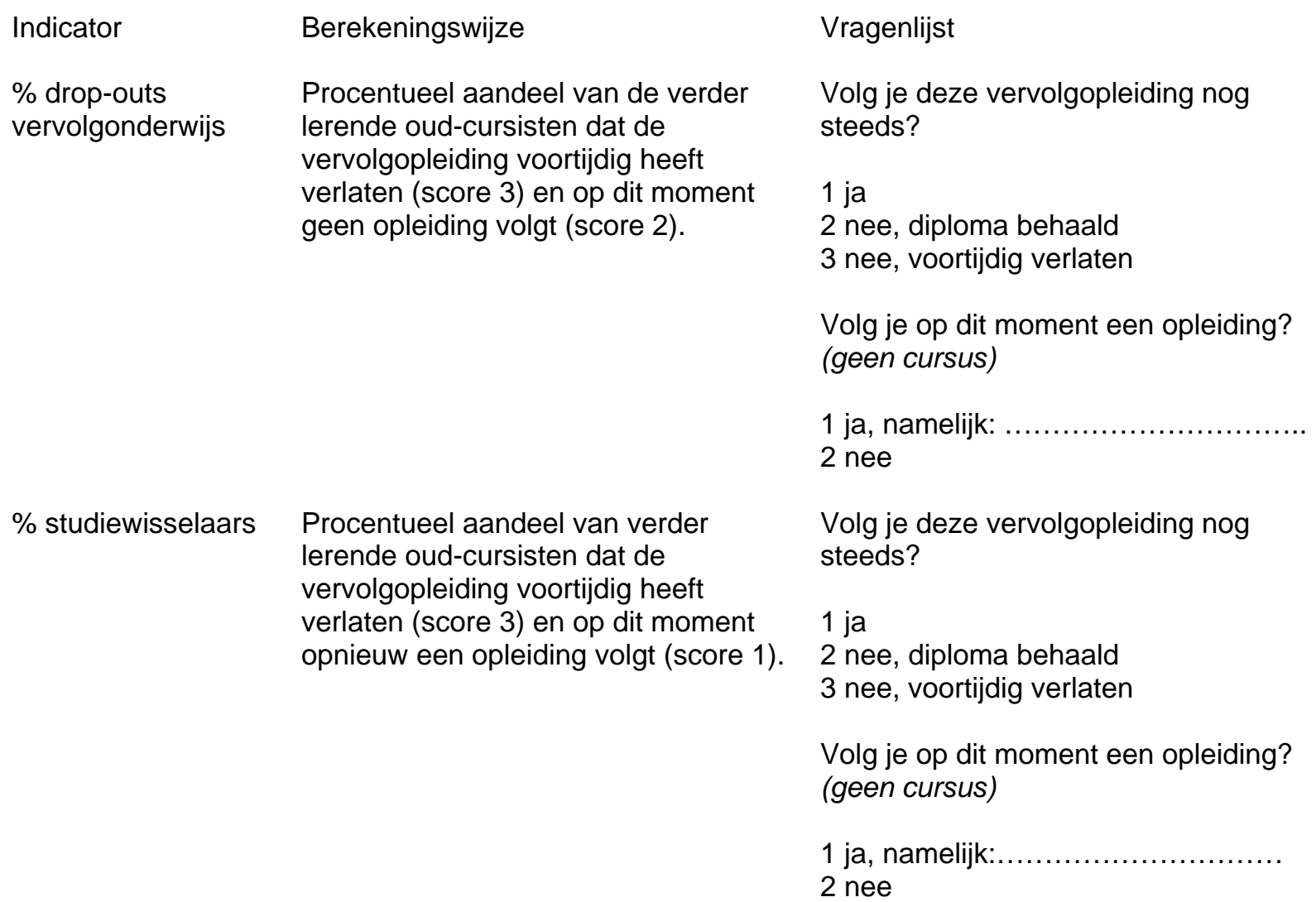




\section{Berekening indicatoren voor het oordeel over de opleiding}

Indicator

Tevreden over studie- en beroepskeuzebegeleiding

Geen problemen bij vinden van BPV- of stageplaats

Tevreden over begeleiding tijdens BPV of stage vanuit school

Tevreden over begeleiding tijdens BPV of stage vanuit BPV- of stageplaats

Opleiding opnieuw kiezen
Berekeningswijze

Procentueel aandeel van de oudcursisten dat tevreden is over de ontvangen hulp bij de studie- of beroepskeuze (score 3, 4 en 5).

Procentueel aandeel van de oudcursisten dat tijdens de opleiding geen problemen heeft ondervonden bij het vinden van een BPV- of stageplaats (score 2).

Procentueel aandeel van de oudcursisten dat tevreden is over de begeleiding tijdens de BPV of stage vanuit school (score 3, 4 en 5).

Procentueel aandeel van de oudcursisten dat tevreden is over de begeleiding tijdens de BPV of stage vanuit BPV- of stageplaats (score 3, 4 en 5).

Procentueel aandeel van de oudcursisten dat, achteraf gezien, opnieuw dezelfde opleiding aan dezelfde school zou kiezen (score $1)$.
Vragenlijst

Hoe tevreden ben je over de hulp die je hebt gehad bij de keuze van een vervolgopleiding of een beroep?

zeer ontevreden <-> zeer tevreden

Heb je tijdens de gevolgde BOL/BBL opleiding problemen ondervonden bij het vinden van een beroepspraktijkvormings- of stageplaats?

1 ja

2 nee

Hoe tevreden ben je over de kwaliteit van de begeleiding tijdens de beroepspraktijkvorming of stage vanuit school?
zeer ontevreden <-> zeer tevreden
$\begin{array}{lllll}1 & 2 & 3 & 4 & 5\end{array}$

Hoe tevreden ben je over de kwaliteit van de begeleiding tijdens de beroepspraktijkvorming of stage vanuit beroepspraktijkvorming- of stageplaats?

zeer ontevreden <-> zeer tevreden

$\begin{array}{lllll}1 & 2 & 3 & 4 & 5\end{array}$

Zou je, achteraf gezien, de door jou gevolgde BOL/BBL opleiding opnieuw kiezen?

$1 \mathrm{ja}$, dezelfde opleiding aan dezelfde school

2 ja, dezelfde opleiding aan een andere school

3 nee, een andere opleiding, namelijk:

4 nee, ik zou niet verder leren 



\section{Bijlage 6 Berekening kwaliteitsindicatoren VMBO}

\section{Berekening indicatoren voor schoolverlaters die zijn gaan werken}

Indicator

Doorstroom naar arbeidsmarkt
Berekeningswijze

Procentueel aandeel van de schoolverlaters dat op het enquêtemoment tenminste 12 uur per week betaald werk verricht, of minder dan 12 uur per week werkzaam is en op zoek is naar betaald werk.

Vragenlijst

Heb je op dit moment betaald werk of volg je een opleiding in het kader van MBO-BBL (leerlingwezen)?

1 ja

2 nee

Zoek je op dit moment (ander) werk?

1 ja

2 nee

Aantal arbeidsuren volgens contract (overuren, uren op school (bij BBL) niet meetellen) uur per week

\section{Aansluiting VMBO-Arbeidsmarkt}

Functieniveau past bij opleidingsniveau

Voldoende aansluiting opleiding-werk

Voldoende benutting van kennis en vaardigheden

Voldoende competenties voor uitoefenen functie
Procentueel aandeel van de betaald werkende schoolverlaters dat een baan heeft op tenminste het eigen niveau (score 2 of hoger).

Procentueel aandeel van de betaald werkende schoolverlaters dat een baan heeft die 'goed' of 'redelijk' aansluit bij de opleiding (score 1 en 2).

Procentueel aandeel van de betaald werkende schoolverlaters dat aangeeft dat hun kennis en vaardigheden voldoende worden benut (score 3, 4 en 5).

Procentueel aandeel van de betaald werkende schoolverlaters dat vindt dat de kennis en vaardigheden niet tekort schieten voor de huidige functie (score 1, 2 en 3)
Vereist opleidingsniveau door werkgever

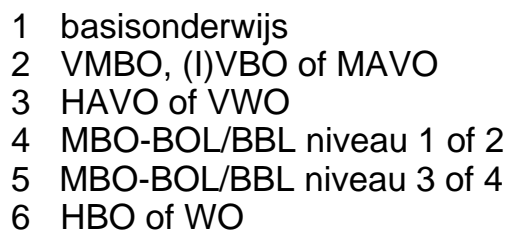

Hoe is de aansluiting tussen de gevolgde VMBO opleiding en je huidige functie?
1 goed
2 redelijk
3 matig
4 slecht

In welke mate worden in je huidige functie je kennis en vaardigheden benut?

$\begin{array}{ccccc}\text { helemaal } & \text { niet } & \text { <-> } & \text { in sterke } & \text { mate } \\ 1 & 2 & 3 & 4 & 5\end{array}$

In welke mate schieten je kennis en vaardigheden tekort voor je huidige functie?

helemaal niet <-> in sterke mate $\begin{array}{lllll}1 & 2 & 3 & 4 & 5\end{array}$ 
Tevreden met huidige functie
Procentueel aandeel van de betaald werkende schoolverlaters dat tevreden is met de functie (score 3, 4 en 5).
Hoe tevreden ben je met je huidige functie?

zeer ontevreden <-> zeer tevreden

\section{Rendement arbeidsmarkt}

Indicator

Werkloosheid

Bruto uurloon

Voldoende

carrièremogelijkheden

\section{Berekeningswijze}

Binnen de groep schoolverlaters die behoren tot de beroepsbevolking (werkenden + werklozen): het percentage schoolverlaters dat zoekt naar betaald werk en op dit moment minder dan 12 uur per week werkzaam is.

\section{Vragenlijst}

Heb je op dit moment betaald werk of volg je een opleiding in het kader van MBO-BBL (leerlingwezen)?

1 ja

2 nee

Zoek je op dit moment (ander) werk?

1 ja

2 nee

Aantal arbeidsuren volgens contract (overuren, uren op school (bij BBL) niet meetellen)

$$
\text { uur per week }
$$

Het bruto uurloon is gelijk aan het bruto maandloon gedeeld door het aantal arbeidsuren per week, vermenigvuldigd met de factor 12/52.

Bruto inkomen per maand (exclusief overuren; inclusief toeslagen)

ongeveer EURO per maand

Aantal arbeidsuren volgens contract (overuren, uren op school (bij BBL) niet meetellen)

uur per week
Procentueel aandeel van de betaald werkende schoolverlaters dat aangeeft dat de functie voldoende carrièremogelijkheden biedt (score 3, 4 en 5).

\section{Oordeel over begeleiding}

Tevreden over studie- en beroepskeuzebegeleiding
Procentueel aandeel van de betaald werkende schoolverlaters dat tevreden is over de ontvangen hulp bij de keuze van een vervolgopleiding of een beroep (score 3, 4 en 5).
Hoe tevreden ben je over de hulp die je hebt gehad bij de keuze van een vervolgopleiding of een beroep?

Biedt je huidige functie goede carrièremogelijkheden?

\begin{tabular}{ccccc} 
& nauwelijks & & $<->$ & \multicolumn{2}{c}{ heel veel } \\
1 & 2 & 3 & 4 & 5
\end{tabular}


Voldoende kwaliteit SBKV informatie
Voor iedere schoolverlater is het percentage van de 9 SBKV onderwerpen (zie LINK)

berekend, waarvan hij of zij de kwaliteit voldoende vindt (score 1 en 2). ${ }^{15}$
Vul voor elk onderwerp in of je de informatie daarover goed, redelijk, matig of slecht vond of dat je over dat onderwerp geen informatie hebt gehad.

Kwaliteit van de informatie

$\begin{array}{cccr}\text { goed redelijk matig slecht } \begin{array}{r}\text { Geen } \\ \text { info } \\ \text { gehad }\end{array} \\ 1 & 2 & 3 & 4\end{array}$

15. Schoolverlaters die bij $>3$ aspecten een missende waarde hebben zijn bij de berekening niet meegenomen. 


\section{Berekening indicatoren voor schoolverlaters die zijn doorgestroomd naar vervolgonderwijs}

Indicator

Doorstroom naar vervolgonderwijs
Berekeningswijze

Procentueel aandeel van de schoolverlaters dat na het verlaten van de opleiding een andere opleiding is gaan volgen (score 1 en 2).
Vragenlijst

Wat ben je na de gevolgde VMBO opleiding gaan doen?

1 vervolgopleiding (géén cursus)

2 vervolgopleiding in combinatie met werk (BBL)

(géén cursus)

3 werken

4 anders, namelijk:

\section{Aansluiting VMBO- vervolgonderwijs}

Doorstroom naar startkwalificerend vervolgtraject

\section{Richting vervolgopleiding past bij opleidingsrichting}

Voldoende aansluiting met vervolgonderwijs

Voldoende begeleiding in vervolgonderwijs
Procentueel aandeel van de verder lerende schoolverlaters dat doorstroomt naar een opleiding op tenminste MBOBOL/BBL niveau 2.

Procentueel aandeel van de verder lerende schoolverlaters met een vervolgopleiding binnen dezelfde sector als de gevolgde VMBO opleiding.

Procentueel aandeel van de verder lerende schoolverlaters dat de aansluiting tussen de gevolgde VMBO opleiding en de vervolgopleiding goed of redelijk vindt (score 1 en 2).

Procentueel aandeel van de verder lerende schoolverlaters dat de begeleiding in het eerste jaar van de vervolgopleiding goed of redelijk vindt (score 1 en 2).
Wat is de naam van deze vervolgopleiding? Vul bij je schooltype je opleidingsrichting in.

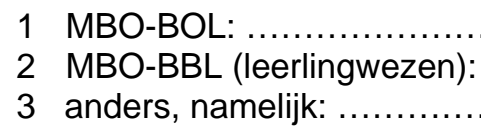

(Indien MBO-BOL of MBO-BBL geef dan ook het niveau aan:)

1 assistentenopleiding(niveau 1 )

2 basisberoepsopleiding (niveau 2)

3 vakopleiding (niveau 3 )

4 middenkaderopleiding (niveau 4)

5 specialistenopleiding (niveau 4)

Wat is de naam van deze vervolgopleiding? Vul bij je schooltype je opleidingsrichting in.

1 MBO-BOL:

2 MBO-BBL (leerlingwezen):

3 anders, namelijk:

Hoe is de aansluiting tussen de gevolgde VMBO opleiding en deze vervolgopleiding?

1 goed

2 redelijk

3 matig

4 slecht

Hoe vind je dat je in het eerste jaar van deze vervolgopleiding bent begeleid?

1 goed

2 redelijk

3 matig

4 slecht 


\section{Rendement vervolgonderwijs}

\begin{tabular}{|c|c|}
\hline Indicator & Berekeningswijze \\
\hline $\begin{array}{l}\% \text { drop-outs } \\
\text { vervolgonderwijs }\end{array}$ & $\begin{array}{l}\text { Procentueel aandeel van de } \\
\text { verder lerende } \\
\text { schoolverlaters dat de } \\
\text { vervolgopleiding voortijdig } \\
\text { heeft verlaten (score } 3 \text { ) en op } \\
\text { dit moment geen opleiding } \\
\text { volgt (score } 2 \text { ). }\end{array}$ \\
\hline$\%$ studiewisselaars & $\begin{array}{l}\text { Procentueel aandeel van de } \\
\text { verder lerende } \\
\text { schoolverlaters dat de } \\
\text { vervolgopleiding voortijdig } \\
\text { heeft verlaten (score } 3 \text { ) en op } \\
\text { dit moment opnieuw een } \\
\text { opleiding volgt (score } 1 \text { ). }\end{array}$ \\
\hline
\end{tabular}

Vragenlijst

Volg je deze vervolgopleiding nog steeds?

1 ja

2 nee, diploma behaald

3 nee, voortijdig verlaten

Volg je op dit moment een opleiding?

1 ja, namelijk:

2 nee

Volg je deze vervolgopleiding nog steeds?

1 ja

2 nee, diploma behaald

3 nee, voortijdig verlaten

Volg je op dit moment een opleiding?

1 ja, namelijk:

2 nee

\section{Oordeel over begeleiding}

Tevreden over

studie- en beroepskeuzebegeleiding

Voldoende kwaliteit SBKV informatie
Procentueel aandeel van de verder lerende

schoolverlaters dat tevreden

is over de ontvangen hulp bij de keuze van een

vervolgopleiding of een beroep (score 3, 4 en 5).

Voor iedere schoolverlater is het percentage van de 9 SBKV onderwerpen (zie LINK) berekend, waarvan hij of zij de kwaliteit voldoende vindt (score 1 en 2). ${ }^{16}$
Hoe tevreden ben je over de hulp die je hebt gehad bij de keuze van een vervolgopleiding of een beroep?

$\begin{array}{ccccc}\text { zeer ontevreden } & <-> & \text { zeer tevreden } \\ 1 & 2 & 3 & 4 & 5\end{array}$

Vul voor elk onderwerp in of je de informatie daarover goed, redelijk, matig of slecht vond of dat je over dat onderwerp geen informatie hebt gehad.

Kwaliteit van de informatie goed redelijk matig slecht Geen info gehad

16. Schoolverlaters die bij $>3$ aspecten een missende waarde hebben zijn bij de berekening niet meegenomen. 